\title{
The Dynamic Nonlinear Effect of Urban Intensity on Natural Resources in Indonesia: Evidence from Asymmetric ARDL and Causality Approaches
}

\author{
Muhammad HASEEB ${ }^{1}$, Beata ŚLUSARCZYK ${ }^{2}$, Hafezali Iqbal HUSSAIN ${ }^{3}$, \\ Kittisak JERMSITTIPARSERT ${ }^{4}$ and Pawet SOBCZAK
}

Authors' affiliations and addresses:

${ }^{1}$ Taylor's Business School, Taylor's University, Lakeside Campus, 1 Jalan Taylors, 47500 Subang Jaya, Malaysia

e-mail: muhammad.haseeb@taylors.edu.my

${ }^{2}$ The Management Faculty, Czestochowa University of Technology, Al. Armii Krajowej 19B, 42-201 Czestochowa, Poland e-mail: beata.slusarczyk@wz.pcz.pl

${ }^{3}$ Taylor's Business School, Taylor's University, Lakeside Campus, 1 Jalan Taylors, 47500 Subang Jaya, Malaysia

University of Economics and Human Sciences in Warsaw, Okopowa 59, 01-043 Warsaw, Poland. e-mail: hafezali.iqbalhussain@taylors.edu.my

${ }^{4}$ Informetrics Research Group, Ton Duc Thang University, Ho Chi Minh City, Vietnam; Faculty of Social Sciences and Humanities, Ton Duc Thang University, Ho Chi Minh City, Vietnam

e-mail: kittisak.jermsittiparsert@tdtu.edu.vn

${ }^{5}$ Faculty of Applied Sciences, WSB University, Cieplaka Street 1c, 41-300 Dąbrowa Górnicza,

Poland

e-mail: psobczak@wsb.edu.pl

*Correspondence:

Beata Ślusarczyk, The Management Faculty, Czestochowa University of Technology, Al. Armii Krajowej 19B, 42-201 Czestochowa,

Poland

tel.: +48343250309

e-mail: beata.slusarczyk@wz.pcz.pl

How to cite this article:

Haseeb, M., Ślusarczyk, B., Hussain, H. I., Jermsittiparsert, K. and Sobczak, P. (2020). The Dynamic Nonlinear Effect of Urban Intensity on Natural Resources in Indonesia: Evidence from Asymmetric ARDL and Causality Approaches. Acta Montanistica Slovaca, Volume 25 (2), 201 212

DOI:

https://doi.org/10.46544/AMS.v25i2.7

\begin{abstract}
The aim of this study is to explore the role of urbanization and economic growth in natural resources using a time series data from 1971 to 2018. The current study applied a novel methodology of nonlinear ARDL proposed by Shin et al. (2014). This methodology is ideal to answer the asymmetric effect on the independent variable on the dependent variable. Furthermore, we also applied asymmetric Granger causality introduced by Hatemi-J (2012) to confirm the causal relationship between the variables. The results of NARDL affirmed that all the variables have a significant impact on natural resources rent. The findings confirm that negative shocks of urban intensity decrease the natural resources rents; however, the positive shocks increase the rents of natural resources. On the one hand, the positive and negative shocks of GDP increase the natural resources though, the magnitude of positive shocks are significantly different from the negative shocks. On the other hand, the results of asymmetric Granger causality confirm that positive and negative shock of urban intensity does granger cause positive shocks of natural resources. Whereas, positive shocks of natural resources (economic growth) have a causal connection with positive and negative shocks of economic growth (natural resources) in Indonesia.
\end{abstract}

\section{Keywords}

Urban intensity, natural resources management, Indonesia, NARDL. 


\section{Introduction}

The term urbanization becomes a global subject which is considered as the outcome of consistent gradual revolutions in the industry based on technical, modern and technological advancements (Ding \& Peng 2018; Bertinelli \& Black, 2004; Fujii, 1968). Moreover, urbanization is said to be the outcome of development, industrialization and economic acceleration (Bakirtas \& Akpolat, 2018), whereby manufacturing organizations explore new and efficient ways of usage, extraction, transformation, and consumption of the natural resources into the products in order to meet the market demand (Ding \& Peng 2018; Bakirtas \& Akpolat, 2018; Nurwanda \& Honjo, 2020). Nevertheless, urbanization results in an ultimate change in resource extraction and utilization, which is also considered as the evaluating criteria for economic development (Ding \& Peng 2018).

It has been reported that while comparing developing countries with developed countries, developing countries are found to be more affected by urbanization (Henderson, 2002). This is because of many reasons including the potential of the economic growth, a rapid increase in the population of the existing residents and due to immigrants shifting from the rural areas to comparatively developed cities (Elmqvist et al., 2013; Yuan, Sawaya, Loeffelholz, \& Bauer, 2005; Meyer \& Meyer, 2016). This leads to the speculation that most of the possible development due to urbanization can happen in medium and small-sized cities (Elmqvist et al., 2013). As mentioned earlier, one of the reasons of the urbanization is consistent growth in the population whereby it was found that in 2015 , the expected population to live in the urban cities are found to be $54 \%$ whereas they are expected to grow up to $74 \%$ of the world's total population by the year 2050 (UN-Habitat, 2016). Moreover, as more people will be living in urban cities, therefore it is also expected that the general lifestyle of the residents will also change (Jones, 2017).

Urbanization leads to several potential challenges to the economy of a country that needs to be taken care of (Jones, 2017). Urbanization results in altering the supply of the basic need and services, which needed to be expanded as per the ratio of urbanization (Ding \& Peng, 2018). Urbanization also results in the potential challenge of housing and land surface usage that need to improve accordingly (Jones, 2017). In addition to this, due to urbanization, the planning related to education, health, employment opportunities also affected that also need to grow in parallel to the urbanization so that the economy can be efficiently managed (Elmqvist et al., 2013). However, the most important challenge of urbanization is the usage and depletion of the natural resources that lead to a potential threat to the ecological health of the country United Nations General Assembly (2017).

The efficient consumption of natural resources significantly contributes to the country's economic growth (Hassan, Xia, Huang, Khan, Iqbal, 2019). Moreover, researchers agree that the natural resources tend to accelerate the economic health of an economy (Miao et al., 2017) and hence results in an accelerated economic growth (Hassan et al., 2018). In addition to this, depletion of natural resources either due to consumption or due to adverse ecological conditions and environmental degradation, has become one of the most important issue mankind is facing globally (Ding \& Peng 2018; Jones, 2017). For instance, it has been reported that mountains, that account for $25 \%$ in terms of the usage of land surface and accommodates one-tenth of the entire global population (Löffler et al., 2011), houses nearly half of the world's total biodiversity (Payne, Warrington, Bennett, 2002 ) is also the source of resources that have been extracted from it including minerals, water, energy, food and others (Blyth, Groombridge, Lysenko, Miles, \& Newton, 2002; Sabishchenko, Rębilas, Sczygiol \& Urbański, 2020). Therefore, urbanization needed to be done in a way that it has the least adverse effects on natural resources, and hence there is a need to have more environment sustainable urbanization (Tomlinson, Chapman, Thornes, \& Baker, 2011; Ding \& Peng 2018). This leads to the emergence of a new agenda named "New Urban Agenda" which is a roadmap for sustainable urbanization signed by more than 170 countries for the next 25 years (Jones, 2017).

Indonesia is a country situated in the Southeast Asia region and is known as the world's largest country in terms of islands with a number of more than 16 thousand islands (The Jakarta Post, 2017). With an area spread over 1,904,569 km2, makes Indonesia 14th largest country in the world (Seeking Alpha, 2017). In terms of population, Indonesia ranks at fort among the most populous counties in the world, with people more than 267 million. According to the World Bank (2016), Indonesia is found to be the most fasting country in Asia in terms of urbanization in which the country is showing a radical transformation from being a rural-based economy to an urban-based. Moreover, it is estimated that by the year 2025 , nearly $68 \%$ of the total population of Indonesia will be living in cities as the cities are growing at a pace of $4.1 \%$ annually. In terms of population density, the country requires more sophisticated urban planning and investments in the infrastructure, which are currently not in accordance with the population and the urbanization (Nurwanda \& Honjo, 2020; Jones, 2017).

Despite being the highest in terms of urbanization, it is estimated that the $1 \%$ urbanization of the county leads to only $4 \%$ of economic growth, which is very low as compared to the other countries in the same region (The World Bank, 2016). Such low economic growth raises serious concern on the rate of urbanization and development (Yan, 2020). When the country urbanization is the fastest of the region, and the population is accordingly increasing, which leads to the more consumption of natural resources, energy utilization, biodiversity mitigation, possible spreading of the population to house more land space, thus urbanizing at the cost of 
the natural resources where the economic growth is not in accordance with the aforementioned facts (Nurwanda \& Honjo, 2020; Jones, 2017). This leads to the serious concerns of the researchers to identify and explore the relationship between urbanization at the cost of natural resources (Ma and Hao, 2020).

In light of the aforementioned discussion, it is evident that though Indonesia is progressing in terms of urbanization; however, the rate of urbanization is not providing sufficient benefits in terms of economic growth. Hence this leads to the motivation of the present study, whereby researchers aim to explore the rate of urbanization at the cost of consumption of natural resources, so that if the empirical results are not good, then the possible implications can be suggested in order to improve the consumption and utilization of the natural resources so that the outcome can be maximized which potentially contribute in the economic growth of the country $n$ the best possible way.

The following sections include discussion related to relevant literature of the urbanization and consumption of the natural resources, followed by the methodology where the operationalization of the present study is discussed. After that, estimations and results are reported, and policy recommendations are discussed based on the findings and results.

\section{Literature Review}

Natural resources are considered as the backbone of an economy since they provide the fundamental advantageous factor of land for the development and progress along with its constituents of minerals, metals, forest, water, etc. In this regard, the theoretical aspects of Natural Resource based theory by Hart (1995) also stated that the efficient utilization of natural resources is considered to cause an increase in firm-level competence. From the macro aspect, assuming the significance of natural resources in an economy, several studies also identified the positive impact of natural resources on country's growth and development (Bunte, Desai, Gbala, Parks \& Runfola, 2018; Sanusi, Meyer \& Ślusarczyk, 2017; Havranek, Horvath \& Zeynalov, 2016; Hao, 2007). However, with increasing trends of industrialization and globalization, there exists a continuous decline in the level of earth's natural resources (Sharif, Afshan and Qureshi, 2019; Gilberthorpe \& Hilson 2016; Popp, Oláh, Fekete, Lakner, \& Máté, 2018; Pegg, 2003).

Moreover, in many recent studies, urbanization has been identified as the major cause of natural resource depletion. For instance, concentrating on urbanization gradients, Parsons et al. (2019) stated that urban development acted as a carnivore commotion for natural habit and act as a major threat to environmental stability and natural resources sustenance. Similarly, in Pakistan, Rashid et al. (2018) also examined the ecological impact of urbanization in the city of Rawalpindi. The findings elaborated that only the two major urban colonies dispersed in the area of 15.5 global hectares are utilizing the resources much greater than the bio-capacity of the entire country. On the other hand, Hassan, Xia, Huang, Khan and Iqbal (2019) studied the causal link between urbanization and natural resources. The results found that in the short run, urbanization has a significant causal effect on natural resources. However, in the long run, there existed no causal link between urbanization and natural resources in Pakistan.

Focusing on the natural resource of coal, Kurniawan and Managi (2018) investigated the relationship between coal usage and urban development in Indonesia between 1970 to 2015. The results of the study found that urbanization is significant to impact coal consumption in the country. Specifically, the findings suggested that a rise in urbanization further enhances the utilization of coal in the Indonesian economy. Similar results were reported by Guo, Zhang, Zhao, Wang and Xi (2018) while examining the Shanxi province of China from 1978 to 2014, and Wang (2018) while studying the coal-urbanization link in twenty-nine provinces of China from the period of 2006 to 2015. In Bangladesh, Arfanuzzaman and Rahman (2017) also found that urban intensity without proper planning in the current age of industrialization has resulted in increased pressure on resources such as power, land, and water. The study found the population to be the major factor in causing increased demand for natural resources. Stressing on the negative effects of increased dependence on fossil fuel in terms of damaging environment and resource depletion, Siddique, Majeed and Ahmad (2016) found that urbanization resulted in increased degradation of natural habitat.

In another study of Indonesia, Remondi, Burlando and Vollmer (2016) analyzed the hydrological impact of urbanization in Jakarta. The study established that as a result of an increase in urban intensity, the tropical river catchments face the challenge in water resources. The study also found the detrimental effects of speedy drastic land utilization as an outcome of urbanization in Indonesia. Similarly, studying the West Java province of Indonesia from the period of 1997 to 2014, Agaton, Setiawan and Effendi (2016) stated that Citarum Watershed is severely endangered by the increase in urbanization and deforestation. Moreover, examining the landscape variation in Indonesia, Arifin and Nakagoshi (2011) also stated that a fast-paced rise in urbanization, especially in a developing country such as Indonesia, contained a detrimental effect on bio-capacity of the country.

In China, Shen, Cheng, Gunson and Wan (2005) examined the relationship between urban development and power and natural resources utilization. In doing so, the authors utilized the data from the period of 1952 to 1999. The study found that urban development is a crucial factor in natural resource depletion. Specifically, the 
findings revealed that predicted that the resource of steel, coal, cement, aluminum, along with timber, are significant to influence the rate of urban intensity. The study also predicted that the trends of urbanization are likely to augment in the future, thereby poses a stronger threat of the extended resource scarcity in the country. Similarly, Ducrot, Le-Page, Bommel and Kuper (2004) also reported that an increase in urban intensity amplified the conflicts for natural resources utilization, hence required the need for advanced management of water and land consumption. Also, Hassan, Xia, Khan and Shah (2019) also studied the role of urbanization in disrupting eco-services. Specifically, the study assessed how the increase in urbanization is associated with the ecological footprint of Pakistan. The authors found that urbanization has a significant negative effect on the demand for natural resources, land, water, etc.

Applying the panel estimations, Bilgili, Koçak, Bulut and Kuloğlu (2017) examined the role of urbanization in affecting energy intensity in Indonesia, Malaysia, China, Nepal, Philippines, Bangladesh, South Korea, Vietnam, India, and Thailand between 1990 to 2014. Similar to Ma (2015) and Hussain, Slusarczyk, Kamarudin, Thaker and Szczepańska-Woszczyna (2020), the study also found the significant positive role of urbanization in increasing energy intensity in the selected Asian economies. In another panel investigation, Bao and Chen (2017) analyzed the factors contributing to water efficiency in thirty-one provinces of China. The findings of the study stated that urbanization reduces the efficiency of water consumption in Chinese provinces. Similarly, Gao and He (2017), while examining the association between urbanization and water consumption in China, also stated that an increase in urbanization enhanced water usage in the country. For India, Raj (2016) also reported that an increase in globalization has resulted in a water supply shortage in Bangalore City.

Moreover, Ma (2015) examined the impact of urbanization on coal and energy intensity. For this, the authors analyzed the data of the Chinese economy from 1986 to 2011. The results of the study found that urban intensity is significantly linked to energy intensity, stating that the rise in urbanization enhanced energy intensity. However, the results failed to find the impact of urbanization on coal intensity in China. Moreover, focusing on wood consumption in the form of timber, Delphin, Escobedo, Abd-Elrahman and Cropper (2016) investigated the impact of urbanization on forestry. In doing so, the study gathered information on the United States economy for the time period of 57 years. The results found that timber volume is largely reduced as a result of urbanization in the state of Florida. Similar results were reported in the study of Zhang and Nagubadi (2005), establishing that urban intensity decreases forestry timbers.

In another study, Ding and Peng (2018) examined the role of urbanization and resource consumption in the mountainous region of Dali Prefecture. The study stated that urban intensity had amplified the impact of people on natural resources. Specifically, the authors found that urban development has greatly affected arable land and thus enhanced the ecological footprint challenges. Similarly, $\mathrm{Wu}, \mathrm{Li}$ and $\mathrm{Li}$ (2018), while analyzing the levels of natural resources in China, stated that Fees of resources are a crucial aspect for the country's growth. However, urbanization, industrialization, and poor usage of natural resources are detrimental to the country's resource sustenance. Similarly, in the case of metal resources, Ma et al. (2016) reported that an increase in urban intensity resulted in contamination and enrichment of metals into the atmosphere. Likewise, in southern Finland, Virkanen (1998) also found that urbanization led to enhance metal deposition in the country.

Furthermore, Wan et al. (2015) stressed on the concept of ecosystem services in the presence of urban growth. For this, the author utilized the data of the Chinese economy from the period of 1990 to 2011 . The study defined ecosystem services as the utilization of natural resources and related assets for the endurance of the population. The investigation found the inverted U-curved association among the variables of interest, indicating that with the increase in urbanization, the level of eco-services also enhanced, however with the growth in urban intensity, the country faces a decline in the level of natural resources and assets. For Brazil, Costa and MonteMór (2015) also found that an increase in urban intensity causes a decline in the management and endurance of natural resources, especially the poor exploitation of land, vegetation, and water resulted in augmented expenditures of sustainable policies. Emphasizing on energy usage from both renewable and non-renewable resources, Kwakwa (2019) examined the contributing factors of enhanced power utilization in Tunisia from the period of 1971 to 2014. Contrarily to earlier findings on resource consumption, the study found that urban development reduces energy utilization in Tunisia.

\section{Methodology}

As discussed earlier, the present study empirically investigates the association between urbanization and consumption of natural resources in the context of Indonesia. Hence in order to meet the objective of the present study, Nonlinear ARDL (NARDL) technique is applied. Moreover, in order to compute the said association and to apply the NARDL, in the present study, the annual data of time series from 1971 to 2018 has been used. In addition to this, the proxy to represent the urban intensity is the total number of urban population (measured in $\%$ of total populations), whereas, for the consumption of natural resources, total natural resources rent (measured in $\%$ of GDP) is used as a proxy. Moreover, we used economic growth as a control variable as it is one of the main reasons to increase natural resources in the Indonesia economy. The data for GDP is measured in per capita of 
GDP. Lastly, the employed data was extracted from the database of the World Bank, which is considered as one of the most reliable time-series data based. Therefore, for the present study, the following empirical equation is being proposed:

$$
\ln \mathrm{NAR}_{\mathrm{t}}=\mathrm{f}\left(\ln \mathrm{URB}_{\mathrm{t}}, \ln \mathrm{GDP}_{\mathrm{t}}\right)
$$

The linear form of equation 1 is stated below:

$$
\ln \mathrm{NAR}_{\mathrm{t}}=\beta+\beta_{1} \ln \mathrm{URB}_{\mathrm{t}}+\beta_{2} \ln \mathrm{GDP}_{\mathrm{t}}+\mu_{\mathrm{t}}
$$

In econometrics, while evaluating the long-run relationship between two or more variables, there are three different approaches available to the researchers. These are Granger Causality, ECM, and ARDL approach (Fareed, Meo, Zulfiqar, Shahzad \& Wang, 2018; Hussain, Grabara, Razimi \& Sharif, 2019). By applying any of these approaches, the asymmetric aspect of the time series data employed is accounted for. In addition to this, the linear aspect of the relationship among variables can be evaluated by linear regression. However, linear regression has the limitation to account for and to handle the nonlinear relationships among the variables. Therefore, Shin et al. (2014) advance the earlier ARDL approaches, which were proposed by Pesaran, Shin and Smith $(1999 ; 2001)$ to account for the nonlinear aspect of the relationships of the variables. By such advancements, the extended framework has the capability to explain the short term-based volatilities and the asymmetric aspect, which are termed as the structural breaks in the time-series data. Therefore, the long-run equation to account for the asymmetric aspect is mentioned below:

$$
\mathrm{NAR}_{\mathrm{t}}=\alpha_{0}+\alpha_{1} \mathrm{URB}_{\mathrm{t}}^{+}+\alpha_{2} \mathrm{URB}_{\mathrm{t}}^{-}+\alpha_{3} \mathrm{GDP}_{\mathrm{t}}^{+}+\alpha_{4} \mathrm{GDP}_{\mathrm{t}}^{-}+\varepsilon_{\mathrm{t}}
$$

In equation 3, natural resources are represented by NAR, whereas $\alpha=\left(\alpha_{0}, \alpha_{1}, \alpha_{3}, \alpha_{4}\right)$ represents the cointegrating vector that needs to be calculated. Moreover, $\mathrm{URB}_{\mathrm{t}}^{+}, \mathrm{URB}_{\mathrm{t}}^{-}, \mathrm{GDP}_{\mathrm{t}}^{+}, \mathrm{GDP}_{\mathrm{t}}^{-}$represents the partial sums of the possible positive and negative changes in natural resources by the urban intensity and economic growth, as shown below.

$$
\begin{aligned}
& \mathrm{URB}_{\mathrm{t}}^{+}=\sum_{\mathrm{t}=1}^{\mathrm{t}} \Delta \mathrm{URB}_{\mathrm{t}}^{+}=\sum_{\mathrm{t}=1}^{\mathrm{t}} \max \left(\mathrm{A} \Delta \mathrm{URB}_{\mathrm{i}}, 0\right) . \\
& \mathrm{URB}^{-}=\sum_{\mathrm{t}=1}^{\mathrm{t}} \Delta \mathrm{URB}_{\mathrm{t}}^{-}=\sum_{\mathrm{t}=1}^{\mathrm{t}} \min \left(\Delta \mathrm{URB}_{\mathrm{i}}, 0\right) \text {. } \\
& \mathrm{GDP}_{\mathrm{t}}^{+}=\sum_{\mathrm{t}=1}^{\mathrm{t}} \Delta \mathrm{GDP}_{\mathrm{t}}^{+}=\sum_{\mathrm{t}=1}^{\mathrm{t}} \max \left(\Delta \mathrm{GDP}_{\mathrm{i}}, 0\right) \text {. } \\
& \mathrm{GDP}_{\mathrm{t}}^{-}=\sum_{\mathrm{t}=1}^{\mathrm{t}} \Delta \mathrm{GDP}_{\mathrm{t}}^{-}=\sum_{\mathrm{t}=1}^{\mathrm{t}} \min \left(\mathrm{AGDP}_{\mathrm{i}}, 0\right) \text {. }
\end{aligned}
$$

Referring to equation 2, the extended asymmetric ARDL framework, which is proposed by Shin et al. (2014) is shown below:

$$
\begin{aligned}
\Delta \mathrm{NAR}_{\mathrm{t}}= & \beta_{0}+\beta_{1} \mathrm{NAR}_{\mathrm{t}-1}+\beta_{2} \mathrm{URB}_{\mathrm{t}-1}^{+}+\beta_{3} \mathrm{URB}_{\mathrm{t}-1}^{-}+\beta_{4} \mathrm{GDP}_{\mathrm{t}-1}^{+}+\beta_{5} \mathrm{GDP}_{\mathrm{t}-1}^{-}+\sum_{\mathrm{i}=1}^{\mathrm{m}} \delta_{1 \mathrm{i}} \Delta \mathrm{NAR}_{\mathrm{t}-1} \\
& +\sum_{\mathrm{i}=0}^{\mathrm{n}} \delta_{2 \mathrm{i}} \Delta \mathrm{URB}_{\mathrm{t}-\mathrm{i}}^{+}+\sum_{\mathrm{i}=0}^{\mathrm{p}} \delta_{3 \mathrm{i}} \Delta \mathrm{URB}_{\mathrm{t}-\mathrm{i}}^{-}+\sum_{\mathrm{i}=0}^{\mathrm{q}} \delta_{4 \mathrm{i}} \Delta \mathrm{GDP}_{\mathrm{t}-\mathrm{i}}^{+}+\sum_{\mathrm{i}=0}^{\mathrm{r}} \delta_{5 \mathrm{i}} \Delta \mathrm{GDP}_{\mathrm{t}-\mathrm{i}}^{-} \\
& +\mathrm{u}_{\mathrm{i}}
\end{aligned}
$$

Referring to equation 8 , lags orders are represented by $m, n, p, q$ and $r$, whereas $\beta_{1}, \beta_{2}, \beta_{3}, \beta_{4}, \beta_{5}$ represents the positive and negative long term shock effects and $\sum_{\mathrm{i}=0}^{\mathrm{n}} \delta_{2 \mathrm{i}}, \sum_{\mathrm{i}=0}^{\mathrm{p}} \delta_{3 \mathrm{i}}, \sum_{\mathrm{i}=0}^{\mathrm{q}} \delta_{4 \mathrm{i}}, \sum_{\mathrm{i}=0}^{\mathrm{r}} \delta_{5 \mathrm{i}}$, represents the potential positive and negative short term on natural resources caused by the urban intensity and economic growth respectively. In the present study, by employing NRDL, the nonlinear based relationship among the variables are being studied and evaluated.

On the other hand, the asymmetric ARDL framework is applied as per the steps discussed by (Fareed, Meo, Zulfiqar, Shahzad \& Wang, 2018). Firstly, all of the variables are evaluated, whether they are stationary or not. Such evaluation is performed by augmented Dickey-Fuller (ADF) and Phillips-Perron (PP) unit root tests. Though the evaluation of stationery is not compulsory when approach like ARDL is applied, and ARDL can be employed when the variables are found stationary at either 1(0), 1(1) or the combination of 1(1) and (0). However, Ibrahim (2015) has discussed that ARDL has the limitation that when the 1(2) series is present, the 
model cannot proceed. Therefore, in order to avoid and eliminate the potential risk associated with the deceptive, tempered, or ambiguous findings, the stationary test was applied. Secondly, referring to Equation 8 , the model is estimated through the ordinary least-squares method. In addition to this, following the guidelines by Katrakilidis and Trachanas (2012), the general to specific approach and SIC information criterion is also followed. Thirdly, the existence of cointegration was evaluated by employing bounds test just to ensure the presence or absence of cointegration. When the presence of cointegration is confirmed, the asymmetric ARDL framework is applied. At this stage, the derivation of the asymmetric cumulative dynamic multiplier effects lead by $1 \%$ change is studied in $\mathrm{URB}_{\mathrm{t}-1}^{+}, \mathrm{URB}_{\mathrm{t}-1}^{-}, \mathrm{GDP}_{\mathrm{t}-1}^{+}, \mathrm{GDP}_{\mathrm{t}-1}^{-}$accordingly. These are shown in the following equations:

$$
\begin{aligned}
& \mathrm{s}_{\mathrm{h}}^{+}(\mathrm{URB})=\sum_{\mathrm{j}=0}^{\mathrm{h}} \frac{\partial \mathrm{NAR}_{\mathrm{t}+\mathrm{i}}}{\partial \mathrm{URB}_{\mathrm{t}-1}^{+}} \\
& \mathrm{s}_{\mathrm{h}}^{-}(\mathrm{URB})=\sum_{\mathrm{j}=0}^{\mathrm{h}} \frac{\partial \mathrm{NAR}_{\mathrm{t}+\mathrm{i}}}{\partial \mathrm{URB}_{\mathrm{t}-1}^{-}} \\
& \mathrm{s}_{\mathrm{h}}^{+}(\mathrm{GDP})=\sum_{\mathrm{j}=0}^{\mathrm{h}} \frac{\partial \mathrm{NAR}_{\mathrm{t}+\mathrm{i}}}{\partial \mathrm{GDP}_{\mathrm{t}-1}^{+}} \\
& \mathrm{s}_{\mathrm{h}}^{-}(\mathrm{GDP})=\sum_{\mathrm{j}=0}^{\mathrm{h}} \frac{\partial \mathrm{NAR}_{\mathrm{t}+\mathrm{i}}}{\partial \mathrm{GDP}_{\mathrm{t}-1}^{-}}
\end{aligned}
$$

Based on the aforementioned discussion, which states the step by step application of NARDL, the objective of the present study is studied and evaluated. The empirical findings of the tests applied, and results are discussed in the next section.

\section{Data Analysis and Interpretation}

Initially, we applied descriptive statistics for all the three variables used in this research. The findings of descriptive statistics are reported in Table 1. It contains mean value, minimum, maximum, standard deviation value along with the Jarque-Bera test, which confirms that whether our variables are linear or nonlinear. The findings confirm that the mean of all the variables is positive. The mean value of natural resources is 10.167 , with a minimum value of 3.059 and a maximum value of 33.658. In addition, the mean value of urban intensity is 35.763 , with a minimum value of 17.338 and a maximum value of 55.325. Moreover, the mean value of economic growth is 2118.153 , with a minimum value of 804.724 and a maximum value of 4284.653 . In addition, the standard deviation for natural resources, economic growth, and urban intensity are 6.022, 966.081, and 12.382. Furthermore, we applied the Jarque-Bera test to confirm the normality in the selected variables. The results of the JB test confirm the rejection of the null hypothesis at a $1 \%$ level of significance, which means all the variables are non-normally distributed. The results of further confirm that there is an indication of nonlinearity in all the selected variables (Troster et al., 2018; Shahbaz et al., 2018; Sharif et al., 2019; Arain et al., 2019).

Tab.1. Results of Descriptive Statistics

\begin{tabular}{|c|c|c|c|}
\hline \multicolumn{5}{|c|}{ Tab.1. Results of Descriptive Statistics } \\
\hline Mean & GDP & NAR & URB \\
\hline Maximum & 2118.153 & 10.167 & 35.763 \\
\hline Minimum & 4284.653 & 33.658 & 55.325 \\
\hline Std. Dev. & 804.724 & 3.059 & 17.338 \\
\hline Skewness & 966.081 & 6.022 & 12.382 \\
\hline Kurtosis & 0.585 & 1.848 & 0.035 \\
\hline Jarque-Bera & 2.383 & 7.152 & 1.585 \\
\hline Probability & 34.500 & 61.786 & 42.017 \\
\hline Source: Authors' Estimations & 0.000 & 0.000 & 0.000 \\
\hline
\end{tabular}

There is one significant requirement of utilizing ARDL bound testing methodology that all of the aeries ought to be stationary at I (0) or I (1) but not I(2). As indicated by Ouattara (2004), the findings of ARDL will be invalid if any of the I (2) factors are considered for the model. Thusly, it is fundamental to decide the stationarity of the dataset. In doing so, we used ADF and PP unit root tests, and the outcomes of the two tests are introduced in Table 2. The unit root test outcomes indicated that natural resources rents, urban intensity, and economic growth are showing not stationary features at the level and then become stationary at the first differential series. Moreover, we likewise utilized Zivot and Andrews' (1992) unit root test, which reflects breaks as contended by 
Perron (1989) that the basic stationary tests give bogus results within sight of breaks to dismiss the null of unit root test. Thinking about the issue of the break in the time series, utilizing Zivot and Andrews (1992) unit root test, we additionally observed that all the factors are stationary at I (1), not I (2) (Table 3). Subsequently, it is affirmed that we can apply ARDL methodology as all the series are not I (2).

Tab. 2. Results of Unit root test

\begin{tabular}{|c|c|c|c|c|c|c|c|c|}
\hline \multirow{3}{*}{ Variables } & \multicolumn{4}{|c|}{ ADF Unit root test } & \multicolumn{4}{|c|}{ PP unit root test } \\
\hline & \multicolumn{2}{|c|}{$\mathrm{I}(0)$} & \multicolumn{2}{|c|}{$\mathrm{I}(1)$} & \multicolumn{2}{|c|}{$\mathrm{I}(0)$} & \multicolumn{2}{|c|}{$\mathrm{I}(1)$} \\
\hline & $\mathrm{C}$ & C\&T & $\mathrm{C}$ & C\&T & $\mathrm{C}$ & C\&T & $\mathrm{C}$ & C\&T \\
\hline GDP & 0.438 & 0.392 & -5.382 & -5.024 & 0.391 & 0.401 & -5.658 & -5.33 \\
\hline NAR & -0.214 & -0.195 & -4.137 & -4.372 & -0.227 & -0.254 & -4.282 & -4.039 \\
\hline URB & -0.827 & -0.785 & -3.486 & -3.773 & -0.754 & -0.795 & -3.435 & -3.238 \\
\hline \multicolumn{9}{|c|}{$\begin{array}{l}\text { Note: GDP explains the per capita of gross domestic product, NAR represents the natural resources rents, and URB describes the } \\
\text { urban population. } \\
\qquad * * *, * * \& * \text { represents level of significance at } 1 \%, 5 \% \text { and } 10 \% \text { respectively. }\end{array}$} \\
\hline
\end{tabular}

Tab. 3. Zivot-Andrews Structural Break Trended Unit Root Test

\begin{tabular}{|c|c|c|c|c|}
\multicolumn{4}{c|}{ Tab. 3. Zivot-Andrews Structural Break Trended Unit Root Test } \\
\hline \multirow{2}{*}{ Variable } & \multicolumn{2}{|c|}{ At Level } & \multicolumn{2}{c|}{ At 1st Difference } \\
\cline { 2 - 5 } & T- Statistics & Time Break & T- Statistics & Time Break \\
\hline GDP & $-0.346(1)$ & 2004 & $-5.483(1)^{* * *}$ & 2002 \\
\hline NAR & $-1.048(1)$ & 2010 & $-5.049(1)^{* * *}$ & 2000 \\
\hline URB & $-0.893(1)$ & 1999 & $-7.724(1)^{* * *}$ & 2015 \\
\hline \multicolumn{7}{|c|}{ Note: Lag order shown in parenthesis. } \\
\hline
\end{tabular}

Moreover, Sharif, Afshan \& Shahzad (2018) asserted that long-term connections rely upon maximum lags, and Stock and Watson (2012) additionally affirmed that utilizing an excessive number of lags or utilizing less lags can avoid most significant information of the framework or may reason worthless valuation. Hence, thinking about the significance of ideal lags, we utilized just 1 lag as ideal after Schwarz Info Criteria (SIC). The results of bound testing, along with nonlinear specifications, are reported in Table 4. The value of F-stats is higher than the upper limits at a 5\% significance level, which affirms the nonlinear long-run relationship between urban intensity, natural resources, and economic growth in Indonesia. In this manner, we can push ahead to estimate nonlinear ARDL coefficients.

Tab. 4. Results of Bond test cointegration in the asymmetric specification

\begin{tabular}{|c|c|c|c|}
\hline Model & F-Statistics & Upper Bond & Lower Bond \\
\hline ln NAR / (ln URB_POS, ln URB_NEG, ln GDP_POS, ln GDP_NEG) & 32.548 & & \\
\hline \multicolumn{4}{|l|}{$\begin{array}{ll} & \text { Critical Values } \\
\end{array}$} \\
\hline $10 \%$ & & 4.463 & 1.735 \\
\hline $5 \%$ & & 5.433 & 2.231 \\
\hline $1 \%$ & & 6.873 & 2.802 \\
\hline $\begin{array}{r}\text { Note: The combine null of no long-run relationship is } \begin{array}{r}\mathrm{p}=0+ \\
=0-0 .\end{array} \\
\text { sample period. }\end{array}$ & cal values ar & ending on $\mathrm{Na}$ & in (2005), the \\
\hline
\end{tabular}

In the next step, we evaluated equation 8 by utilizing the general approach utilizing $p=q=1$ as an ideal lag selection. The leading investigation of Shin et al. (2014) additionally pursued this way to deal with the final description of the nonlinear ARDL framework. Here, we did not use all the lag regressors, which are insignificant, as indicated by the general approach since Katrakilidis and Trachanas (2012) proposed expelling unimportant lag regressors is vital as insignificant lag regressors can make clamor in the graphical plot multipliers. Moreover, we likewise checked other significant issues of NARDL, for example, heteroskedasticity utilizing the BPG test, serial correlation utilizing the LM test, and specification of the model using the Ramsey RESET test. The findings of the diagnostic test are reported in table 7 . The results affirmed that the framework is not experiencing any of the previously mentioned problems; along these lines, we can push toward a novel estimation of the NARDL approach. The NARDL estimation findings are reported in Table 5. 
Tab. 5. Estimations using NARDL Approach

\begin{tabular}{|c|c|c|c|}
\hline Variables & Coeff. & t-stats & Prob. \\
\hline C & 2.048 & 3.088 & 0.005 \\
\hline In NAR (-1) & 0.384 & 5.372 & 0.000 \\
\hline In URB_NEG & 0.284 & 4.684 & 0.000 \\
\hline In URB_POS & 0.176 & 3.785 & 0.000 \\
\hline In GDP_NEG (-1) & -0.133 & -1.960 & 0.050 \\
\hline In GDP_POS (-1) & 0.295 & 4.547 & 0.000 \\
\hline DlnURB_NEG (-1) & 0.216 & 4.628 & 0.000 \\
\hline DlnURB_POS (-1) & 0.149 & 3.957 & 0.000 \\
\hline DlnGDP_NEG (-1) & 0.206 & -4.515 & 0.000 \\
\hline DlnGDP_POS (-1) & 0.124 & 2.019 & 0.050 \\
\hline Note:_POS \& NEG reflects to partial sum of positive and negative \\
\hline
\end{tabular}

The present study investigates the asymmetric effect of urban intensity and economic growth on natural resources in Indonesia. The results of long-run asymmetric ARDL is reported in Table-6. The results affirmed that there is a presence of an asymmetric connection between urban intensity and natural resources and economic growth and natural resources in the Indonesian economy. The results further suggested that due to the negative shocks of urban intensity, the natural resources rents decreased by $20.4 \%$. However, because of the positive shocks of urban intensity, the natural resources rents increase by $35.5 \%$. The signs of both shocks are different, which affirm a nonlinear relationship between urban intensity and natural resources. The findings are very logical and justifiable as the number of people increases in urban areas; the needs of natural resources increase as compared if people live in rural areas. On the other hand, the effect of economic growth on natural resources is also significant and asymmetric in nature. The negative shocks in GDP increase the natural resources rent by $18.3 \%$. However, the positive shocks in GDP increase the natural resources by $38.5 \%$. The signs of both shocks are the same, but the magnitudes are different, which suggested that there is an asymmetric relationship between economic growth and natural resources. This means that, as the economic growth increase of decrease, it will increase the needs of natural resources with a different magnitude as low growth increase natural resources rent significantly lower in comparison with higher growth in the Indonesia economy.

Tab. 6. Results of Long-run asymmetric using NARDL Approach

\begin{tabular}{|c|c|c|c|}
\hline Variables & Coeff. & t-stats & Prob. \\
\hline In URB_NEG & -0.204 & 4.548 & 0.000 \\
\hline ln URB_POS & 0.353 & 4.968 & 0.000 \\
\hline ln GDP_NEG & 0.183 & 2.904 & 0.004 \\
\hline ln GDP_POS & 0.385 & 5.411 & 0.000 \\
\hline \multicolumn{4}{|l}{} \\
\hline
\end{tabular}

Source: Authors' Estimations

Next, the results of the diagnostic test of the NARDL approach are reported in Table 7. Here, the significance value of LM and Breusch-Pagan-Godfrey is greater than $0.100(10 \%)$, which confirms that the model is independent of serial correlation and heteroscedasticity issues. In addition, we reported the p-value of the Ramsay RESET test, which is also more than 0.100 , suggesting that the current model is suitably specified. Finally, we reported the variance inflation factor value, which is 4.583 , suggesting that there is no problem of multicollinearity in our model.

Tab. 7. Results of Diagnostic Test

\begin{tabular}{|c|c|c|c|}
\hline Diagnostic Test & Problem & P-value & Status \\
\hline LM test & Serial Correlation & 0.148 & No serial correlation \\
\hline Breusch-Pagan-Godfrey & Heteroscedasticity & 0.227 & No heteroscedasticity \\
\hline Ramsey RESET test & Model specification & 0.583 & Model is correct \\
\hline VIF & Multicollinearity & 4.582 & No multicollinearity \\
\hline Source: Authors' Estimations
\end{tabular}

Source: Authors' Estimations

In the final step, we applied the asymmetric Granger causality, which is proposed by Hatemi-j (2012). We used asymmetric causality to examine the causal connection between the positive and negative shocks natural resources, urban intensity, and economic growth in the Indonesia economy. The results are reported in Table-8. The results suggested a unidirectional causal relationship from negative shocks of urban intensity and positive shocks o natural resources. Moreover, the results further suggested a unidirectional causal connection from the positive shock of urban intensity to positive shocks of natural resources. On the other hand, the causal 
connection between economic growth and natural resources rent is significant. We found a bidirectional causal connection between positive shocks of natural resources to positive and negative shocks of economic growth and positive shocks of economic growth to positive and negative shocks of natural resources rents in the Indonesian economy. However, we do not find any causal connection from negative shocks of natural resources rents to the positive and negative shock of urban intensity and economic growth.

Tab. 8. Results of Asymmetric Granger Causality

\begin{tabular}{|c|c|c|c|c|}
\hline Null hypothesis & Wald Test & Bstrap 1\% & Bstrap 5\% & Bstrap 10\% \\
\hline$N A R^{-}$does not Granger cause $U R B^{-}$ & 4.483 & 19.372 & 14.472 & 9.372 \\
\hline$N_{A R^{-}}$does not Granger cause $U R B^{+}$ & 2.048 & 8.483 & 6.613 & 4.874 \\
\hline$N_{A R^{+}}$does not Granger cause ${ }^{U R B^{-}}$ & 0.483 & 10.746 & 8.313 & 5.382 \\
\hline $\mathrm{NAR}^{+}$does not Granger cause $U R B^{+}$ & 1.484 & 24.584 & 19.485 & 16.897 \\
\hline$U R B^{-}$does not Granger cause $N A R^{-}$ & 3.694 & 7.692 & 6.039 & 4.593 \\
\hline$U R B^{-}$does not Granger cause $N A R^{+}$ & $26.483 * * *$ & 14.483 & 11.962 & 9.493 \\
\hline$U R B^{+}$does not Granger cause $N A R^{-}$ & 4.932 & 9.766 & 7.491 & 5.882 \\
\hline$U R B^{+}$does not Granger cause $N_{A R^{+}}$ & $19.496 * * *$ & 9.521 & 7.804 & 6.087 \\
\hline$N_{A R^{-}}$does not Granger cause $G D P^{-}$ & 0.483 & 15.584 & 11.421 & 8.572 \\
\hline NAR $^{-}$does not Granger cause $G D P^{+}$ & 4.797 & 19.385 & 10.096 & 7.381 \\
\hline$N_{A R^{+}}$does not Granger cause $G D P^{-}$ & $53.390 * * *$ & 23.584 & 18.009 & 15.882 \\
\hline NAR $^{+}$does not Granger cause $G D P^{+}$ & $38.511 * * *$ & 16.900 & 13.548 & 10.596 \\
\hline$G D P^{-}$does not Granger cause $N^{-}$ & 4.583 & 18.795 & 12.001 & 9.593 \\
\hline$G D P^{-}$does not Granger cause $N A R^{+}$ & 0.427 & 14.778 & 9.493 & 7.842 \\
\hline$G D P^{+}$does not Granger cause $N A R^{-}$ & $9.584 * * *$ & 7.483 & 4.583 & 1.484 \\
\hline$G D P^{+}$does not Granger cause NAR $^{+}$ & $46.651 * * *$ & 19.584 & 14.642 & 10.037 \\
\hline
\end{tabular}

Note: $* * *$ and $* * *$ indicate statistical significance at 10,5 and $1 \%$ level respectively. Critical values are obtained from 10000 bootstrap replications.

\section{Discussion and Conclusion}

Urbanization also results in the potential challenge of housing and land surface usage that need to improve accordingly. In addition to this, due to urban intensity, the planning related to education, health, employment opportunities also affected that also need to grow in parallel to the urbanization so that the economy can be efficiently managed. However, the most important challenge of urbanization is the usage and depletion of the natural resources that lead to a potential threat to ecological health. In doing so, the aim of this study is to explore the rate of urbanization at the cost of consumption of natural resources. The current study applied a novel methodology of nonlinear ARDL proposed by Shin et al. (2014). This methodology is ideal to answer the asymmetric effect on the independent variable on the dependent variable. Furthermore, we also applied asymmetric Granger causality introduced by Hatemi-J (2012) to confirm the causal relationship between the variables. The results of NARDL affirmed that all the variables have a significant impact on natural resources rent. The findings confirm that negative shocks of urban intensity decrease the natural resources rents; however, the positive shocks increase the rents of natural resources. On the one hand, the positive and negative shocks of GDP increase the natural resources though, the magnitude of positive shocks are significantly different from the negative shocks. On the other hand, the results of asymmetric Granger causality confirm that positive and negative shock of urban intensity does granger cause positive shocks of natural resources. Whereas, positive shocks of natural resources (economic growth) have a causal connection with positive and negative shocks of economic growth (natural resources) in Indonesia. The current study recommends that the Indonesia government and policymakers need to provide a better life and earning opportunities in the rural areas, so the people do not travel more towards urban areas, which ultimately helps to reduce natural resources.

\section{References}

Agaton, M., Setiawan, Y., \& Effendi, H. (2016). Land use/land cover change detection in an urban watershed: a case study of upper Citarum Watershed, West Java Province, Indonesia. Procedia Environmental Sciences, 33, 654-660, doi: 10.1016/j.proenv.2016.03.120

Arain, H., Han, L., Sharif, A., \& Meo, M. S. (2019). Investigating the effect of inbound tourism on FDI: The importance of quantile estimations. Tourism Economics, DOI: 10.1177/1354816619859695 
Arfanuzzaman, M., \& Rahman, A. A. (2017). Sustainable water demand management in the face of rapid urbanization and ground water depletion for social-ecological resilience building. Global Ecology and Conservation, 10, 9-22, https://doi.org/10.1016/j.gecco.2017.01.005

Arifin, H. S., \& Nakagoshi, N. (2011). Landscape ecology and urban biodiversity in tropical Indonesian cities. Landscape and ecological engineering, 7(1), 33-43, DOI 10.1007/s11355-010-0145-9

Bahmani-Oskooee, M., \& Bohl, M. T. (2000). German monetary unification and the stability of the German M3 money demand function. Economics letters, 66(2), 203-208, https://doi.org/10.1016/S0165-1765(99)00223-2

Bakirtas, T., \& Akpolat, A. G. (2018). The relationship between energy consumption, urbanization, and economic growth in new emerging-market countries. Energy, 147, 110-121, https://doi.org/10.1016/j.energy.2018.01.011

Bao, C., \& Chen, X. (2017). Spatial econometric analysis on influencing factors of water consumption efficiency in urbanizing China. Journal of Geographical Sciences, 27(12), 1450-1462, https://doi.org/10.1007/s11442017-1446-9

Bertinelli, L., \& Black, D. (2004). Urbanization and growth. Journal of Urban Economics, 56(1), 80-96.

Bilgili, F., Koçak, E., Bulut, Ü., \& Kuloğlu, A. (2017). The impact of urbanization on energy intensity: Panel data evidence considering cross-sectional dependence and heterogeneity. Energy, 133, 242-256, https://doi.org/10.1016/j.energy.2017.05.121

Blyth, S.; Groombridge, B.; Lysenko, I.; Miles, L.; Newton, A. (2002). Mountain Watch, Environmental Change and Sustainable Development in Mountains; UNEP-WCMC: Cambridge, UK; p. 11.

Bunte, J. B., Desai, H., Gbala, K., Parks, B., \& Runfola, D. M. (2018). Natural resource sector FDI, government policy, and economic growth: Quasi-experimental evidence from Liberia. World Development, 107, 151162, https://doi.org/10.1016/j.worlddev.2018.02.034

Costa, H. S., \& Monte-Mór, R. L. (2015). Urbanization \& Environment: trends and patterns in contemporary Brazil. Livros, 125-146.

Delphin, S., Escobedo, F. J., Abd-Elrahman, A., \& Cropper, W. P. (2016). Urbanization as a land use change driver of forest ecosystem services. Land Use Policy, 54, 188-199, https://doi.org/10.1016/j.landusepol.2016.02.006

Ding, Y., \& Peng, J. (2018). Impacts of urbanization of mountainous areas on resources and environment: Based on ecological footprint model. Sustainability, 10(3), 765, https://doi.org/10.3390/su10030765

Ducrot, R., Le Page, C., Bommel, P., \& Kuper, M. (2004). Articulating land and water dynamics with urbanization: an attempt to model natural resources management at the urban edge. Computers, Environment and Urban Systems, 28(1-2), 85-106, https://doi.org/10.1016/S0198-9715(02)00066-2

Elmqvist, T., Fragkias, M., Goodness, J., Güneralp, B., Marcotullio, P. J., McDonald, R. I., ... \& Wilkinson, C. (Eds.). (2013). Urbanization, biodiversity and ecosystem services: challenges and opportunities: a global assessment. Springer.

Fareed, Z., Meo, M. S., Zulfiqar, B., Shahzad, F., \& Wang, N. (2018). Nexus of tourism, terrorism, and economic growth in Thailand: new evidence from asymmetric ARDL cointegration approach. Asia Pacific Journal of Tourism Research, 23(12), 1129-1141, https://doi.org/10.1080/10941665.2018.1528289

Fujii, T. (1966). Industrization, urbanization and economic growth. Econ. Rev. 17, 368-372.

Gao, S., \& He, Y. (2017). The Effect of Urbanization and Economic Performance on Metropolitan Water Consumption: Theoretic Model and Evidence from Guangzhou of China. Applied Economics and Finance, 4(2), 163-171, https://doi.org/10.11114/aef.v4i2.2076

Gilberthorpe, E., \& Hilson, G. (Eds.). (2016). Natural resource extraction and indigenous livelihoods: Development challenges in an era of globalization. Routledge.

Guo, X., Zhang, Z., Zhao, R., Wang, G., \& Xi, J. (2018). Association between coal consumption and urbanization in a coal-based region: a multivariate path analysis. Environmental Science and Pollution Research, 25(1), 533-540, https://doi.org/10.1007/s11356-017-0436-x

Hao, L. (2007). Natural Resource and Economic Growth: Resource Bottleneck and its Solution [J]. Economic Research Journal, 6, 142-153,

Hatemi-j, A. (2012). Asymmetric causality tests with an application. Empirical Economics, 43(1), 447-456, https://doi.org/10.1007/s00181-011-0484-x

Hart, S. L. (1995). A natural-resource-based view of the firm. Academy of management review, 20(4), 986-1014.

Hassan, S. T., Xia, E., Huang, J., Khan, N. H., \& Iqbal, K. (2019). Natural resources, globalization, and economic growth: evidence from Pakistan. Environmental Science and Pollution Research, 26(15), 1552715534, https://doi.org/10.1007/s11356-019-04890-z

Hassan, S. T., Xia, E., Khan, N. H., \& Shah, S. M. A. (2019). Economic growth, natural resources, and ecological footprints: evidence from Pakistan. Environmental Science and Pollution Research, 26(3), 29292938, https://doi.org/10.1007/s11356-018-3803-3

Havranek, T., Horvath, R., \& Zeynalov, A. (2016). Natural resources and economic growth: a metaanalysis. World Development, 88, 134-151, https://doi.org/10.1016/j.worlddev.2016.07.016 
Henderson, V. (2002). Urbanization in developing countries. The World Bank Research Observer, 17(1), 89112. https://doi.org/10.1093/wbro/17.1.89.

Hussain, H.I., Grabara, J., Razimi, M.S.A., \& Sharif, S.P. (2019) Sustainability of Leverage Levels in Response to Shocks in Equity Prices: Islamic Finance as a Socially Responsible Investment, Sustainability, 11 (12), 3260. https://doi.org/10.3390/su11123260.

Hussain, H.I., Slusarczyk, B., Kamarudin, F., Thaker, H.M.T., Szczepańska-Woszczyna, K. (2020) An investigation of an adaptive neuro-fuzzy inference system to predict the relationship among energy intensity, globalization, and financial development in major ASEAN economies. Energies, 13 (4), art. no. 850. doi: 10.3390/en13040850

Ibrahim, M. H. (2015). Oil and food prices in Malaysia: a nonlinear ARDL analysis. Agricultural and Food Economics, 3(1), 1-14, https://doi.org/10.1186/s40100-014-0020-3

Katrakilidis, C., \& Trachanas, E. (2012). What drives housing price dynamics in Greece: New evidence from asymmetric ARDL cointegration. Economic $\quad$ Modelling, 29(4), 1064-1069, https://doi.org/10.1016/j.econmod.2012.03.029

Kurniawan, R., \& Managi, S. (2018). Coal consumption, urbanization, and trade openness linkage in Indonesia. Energy policy, 121, 576-583, https://doi.org/10.1016/j.enpol.2018.07.023

Kwakwa, P. A. (2019). Towards Sustainable Energy: What Have Natural Resource Extraction, Political Regime and Urbanization Got to Do With it?. Parameters, 1, 1; DOI: 10.22109/JEMT.2019.152097.1132

Löffler, J.; Anschlag, K.; Baker, B.; Finch, O.-D.; Wundram, D.; Diekkrüger, B.; Schröder, B.; Pape, R.; Lundberg, A. (2011). Mountain ecosystem response to global change. Erdkunde, 6, 189-213, DOI: 10.3112/erdkunde.2011.02.06

Ma, B. (2015). Does urbanization affect energy intensities across provinces in China? Long-run elasticities estimation using dynamic panels with heterogeneous slopes. Energy Economics, 49, 390-401, https://doi.org/10.1016/j.eneco.2015.03.012

Ma, Y. \& Hao, Q. (2020) Innovation of Economic Management under Economic Globalization based on Cognitive and Behavioral Sciences, Revista Argentina de Clínica Psicológica, 29 (2), 846 - 853.

Ma, J., Liu, Y., Yu, G., Li, H., Yu, S., Jiang, Y., ... \& Lin, J. (2016). Temporal dynamics of urbanization-driven environmental changes explored by metal contamination in surface sediments in a restoring urban wetland park. Journal of hazardous materials, 309, 228-235, https://doi.org/10.1016/j.jhazmat.2016.02.017

Meyer, D.F., Meyer, N. (2016). A comparative analysis of the perceptions of business chambers in rural and urban South Africa on the developmental role of local government. Polish Journal of Management Studies, 14(1), 152-162, DOI: 10.17512/pjms.2016.14.1.14

Miao, C., Fang, D., Sun, L., \& Luo, Q. (2017). Natural resources utilization efficiency under the influence of green technological innovation. Resources, Conservation and Recycling, 126, 153-161, https://doi.org/10.1016/j.resconrec.2017.07.019

Nurwanda, A., \& Honjo, T. (2020). The prediction of city expansion and land surface temperature in Bogor City, Indonesia. Sustainable Cities and Society, 52, 101772, https://doi.org/10.1016/j.scs.2019.101772

Ouattara, B. (2004). Modelling the long run determinants of private investment in Senegal. The School of Economics Discussion Paper Series 0413. Economics, The University of Manchester.

Parsons, A. W., Rota, C. T., Forrester, T., Baker-W hatton, M. C., M cShea, W . J., Schuttler, S. G., ... \& Kays, R. (2019). Urbanization focuses carnivore activity in remaining natural habitats, increasing species interactions. Journal of Applied Ecology, 56(8), 1894-1904, https://doi.org/10.1111/1365-2664.13385

Payne, K.;Warrington, S.; Bennett, O. (2002). High Stakes: The Future for Mountain Societies; London England Panos Institute: London, UK.

Pegg, S. (2003). Globalization and natural-resource conflicts. Naval War College Review, 56(4), 82-96.

Perron, P. (1989). The great crash, the oil price shock, and the unit root hypothesis. Econometrica: Journal of the Econometric Society, 57(6), 1361-1401, DOI: 10.2307/1913712

Pesaran, M. H., Shin, Y., \& Smith, R. J. (2001). Bounds testing approaches to the analysis of level relationships. Journal of applied econometrics, 16(3), 289-326, https://doi.org/10.1002/jae.616

Pesaran, M. H., Shin, Y., \& Smith, R. P. (1999). Pooled mean group estimation of dynamic heterogeneous panels. Journal of the American Statistical Association, 94(446), 621-634.

Popp, J., Oláh, J., Fekete, M.F., Lakner, Z., \& Máté, D. (2018) The relationship between prices of various metals, oil and scarcity. Energies, 11(9), art. no. 2392, https://doi.org/10.3390/en11092392

Raj, K. (2016). Urbanization and Water Supply: An Analysis of Unreliable Water Supply in Bangalore City, India. In Nature, Economy and Society (pp. 113-132). Springer, New Delhi.

Remondi, F., Burlando, P., \& Vollmer, D. (2016). Exploring the hydrological impact of increasing urbanisation on a tropical river catchment of the metropolitan Jakarta, Indonesia. Sustainable Cities and Society, 20, 210221, https://doi.org/10.1016/j.scs.2015.10.001

Sanusi, K.A., Meyer, D., Ślusarczyk, B. (2017). The relationship between changes in inflation and financial development. Polish Journal of Management Studies, 16(2), 253-265, DOI: 10.17512/pjms.2017.16.2.22 
Seeking Alpha (2017). "Indonesia - The Next Major Oil Importer?". Archived from the original on 6 February 2017. Retrieved 6 February 2017.

Shahbaz, M., Zakaria, M., Shahzad, S. J. H., \& Mahalik, M. K. (2018). The energy consumption and economic growth nexus in top ten energy-consuming countries: Fresh evidence from using the quantile-on-quantile approach. Energy Economics, 71, 282-301, https://doi.org/10.1016/j.eneco.2018.02.023

Sharif, A., Afshan, S., \& Khan, B. S. (2018). Does democracy embolden economic growth in Pakistan? Evidence from ARDL bound testing and rolling window analysis. International Journal of Economics and Business Research, 15(2), 180-203, https://doi.org/10.1504/IJEBR.2018.089684

Sharif, A., Afshan, S., \& Qureshi, M. A. (2019). Idolization and ramification between globalization and ecological footprints: evidence from quantile-on-quantile approach. Environmental Science and Pollution Research, 26(11), 11191-11211, https://doi.org/10.1007/s11356-019-04351-7

Shen, L., Cheng, S., Gunson, A. J., \& Wan, H. (2005). Urbanization, sustainability and the utilization of energy and mineral resources in China. Cities, 22(4), 287-302, https://doi.org/10.1016/j.cities.2005.05.007

Shin, Y., Yu, B., \& Greenwood-Nimmo, M. (2014). Modelling asymmetric cointegration and dynamic multipliers in a nonlinear ARDL framework. In Festschrift in honor of Peter Schmidt (pp. 281-314). Springer, New York, NY.

Siddique, H. M. A., Majeed, M. T., \& Ahmad, H. K. (2016). The Impact of Urbanization and Energy Consumption on CO 2 Emissions in South Asia. South Asian Studies (1026-678X), 31(2).

Sabishchenko, O., Rębilas, R., Sczygiol, N., Urbański, M. (2020). Ukraine energy sector management using hybrid renewable energy systems. Energies, 13 (7), art. no. 1776, doi: 10.3390/en13071776

Stock, J., \& Watson, M. (2012). Disentangling the channels of the 2007-2009 recession (WP no. 18094). Cambridge, MA: NBER. doi:10.3386/w18094

The Jakarta Post. (2017). 16,000 Indonesian islands registered at UN". 21 August 2017. Archived from the original on 30 November 2018. Retrieved 3 December 2018.

The World Bank (2016). Retrieved from: https://www.worldbank.org/en/news/feature/2016/06/14/indonesiaurban-story

Tomlinson, C. J., Chapman, L., Thornes, J. E., \& Baker, C. J. (2011). Including the urban heat island in spatial heat health risk assessment strategies: a case study for Birmingham, UK. International journal of health geographics, 10(1), 42, https://doi.org/10.1186/1476-072X-10-42

Troster, V., Shahbaz, M., \& Uddin, G. S. (2018). Renewable energy, oil prices, and economic activity: A Granger-causality in quantiles analysis. Energy Economics, 70, 440-452, https://doi.org/10.1016/j.eneco.2018.01.029

UN-Habitat. (2016). Urbanization and Development: Emerging Futures. World Cities Report. Nairobi, Africa. Available online: https://unhabitat.org/wp-content/uploads/2014/03/WCR-\%20Full-Report-2016.pdf (accessed on 30 May 2017).

United Nations General Assembly (2017). New Urban Agenda. Available online: http:/habitat3.org/thenewurban-agenda/

Virkanen, J. (1998). Effect of urbanization on metal deposition in the bay of Töölönlahti, Southern Finland. Marine Pollution Bulletin, 36(9), 729-738, https://doi.org/10.1016/S0025-326X(98)00053-8

Wan, L., Ye, X., Lee, J., Lu, X., Zheng, L., \& Wu, K. (2015). Effects of urbanization on ecosystem service values in a mineral resource-based city. Habitat International, 46, 54-63, https://doi.org/10.1016/j.habitatint.2014.10.020

Wang, S. (2018). Impact of Urbanization of Coal Consumption in China. Retrieved from https://repository.library.georgetown.edu/handle/10822/1050875

$\mathrm{Wu}, \mathrm{S}$., Li, L., \& Li, S. (2018). Natural resource abundance, natural resource-oriented industry dependence, and economic growth: Evidence from the provincial level in China. Resources, Conservation and Recycling, 139, 163-171, https://doi.org/10.1016/j.resconrec.2018.08.012

Yan, W. (2020) Multi-Factor Check-and-Balance Mechanism of the Spread of Urban Financial Emergencies and Public Psychological Acceptance, Revista Argentina de Clínica Psicológica, 29 (2), 200 - 206.

Yuan, F., Sawaya, K. E., Loeffelholz, B. C., \& Bauer, M. E. (2005). Land cover classification and change analysis of the Twin Cities (Minnesota) Metropolitan Area by multi temporal Landsat remote sensing. Remote sensing of Environment, 98(2-3), 317-328, https://doi.org/10.1016/j.rse.2005.08.006

Zhang, D., \& Nagubadi, R. V. (2005). The influence of urbanization on timberland use by forest type in the

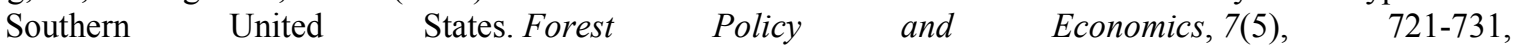
https://doi.org/10.1016/j.forpol.2005.03.002

Zivot, E., \& Andrews, D. W. K. (1992). Further evidence on the great crash, the oil-price shock, and the unitroot hypothesis. Journal of business \& economic statistics, 20(1), 25-44. 